\title{
THE EFFECT OF SARULLA NATURAL NANOZEOLITE ADDITION IN THE PREPARATION OF NANOCOMPOSITE FOAM POLYURETHANTSVIEWED FROM FTIR CHARACTERIZATION
}

\author{
Oleh: \\ Fransiskus Gultom ${ }^{1)}$ \\ dan Hernawaty ${ }^{2)}$ \\ Universitas Darma Agung, Medan ${ }^{1,2)}$ \\ dan STKIP Riama, Medan ${ }^{1,2)}$ \\ E-mail: \\ fransiskusgultom2277@gmail.com ${ }^{1)}$ \\ dan hernawatysihotang1973@gmail.com ${ }^{2)}$
}

\begin{abstract}
The fabrication and characterization of polyurethane foam nanocomposites with the addition of Sarulla natural nanozeolite fillers has been investigated. The steps carried out in research on the manufacture of polyurethane foam nanocomposites are: 1) Preparation and purification of natural zeolites, 2) Preparation of nanozeolites, and 3) Preparation of polyurethane foam nanocomposites is carried out using an in situ process by mixing natural nanozeolites in a mixture of polypropylene glycol and toluene diisocyanate. The results of the particle size analyzer show Sarulla nanozeolite particle size is $95.8 \mathrm{~nm}$. The XRF results showed that the main composition of Sarulla nanozeolites was $\mathrm{SiO}_{2}(80.98 \%)$ and $\mathrm{Al}_{2} \mathrm{O}_{3}(14.21 \%)$, while the XRD results showed that Sarulla nanozeolites were Mordenite types. Variation in weight ratio of nanozeolites as fillers to polypropylene glycol and toluene diisocyanate is (0, 5, 10, 15, 20 and 25)\%. The results of the FTIR spectrum of polyurethane foam and polyurethane foam nanocomposite show almost the same functional groups, this is caused by the interaction that occurs between polyurethane foam and nanozeolite is a physical reaction.
\end{abstract}

Keywords: Nanocomposite, Polyurethane Foam, Natural Zeolite, and FTIR

\begin{abstract}
ABSTRAK
Pembuatan dan karakterisasi nanokomposit busa poliuretan dengan penambahan pengisi nanozeolit alam Sarulla telah diteliti. Tahap yang dilakukan dalam penelitian pada pembuatan nanokomposit busa poliuretan adalah: 1) Persiapan dan


pemurnian zeolit alam, 2) Pembuatan nanozeolit, dan 3) Pembuatan nanokomposit busa poliuretan dilakukan menggunakanprosesin situ dengan caramencampurkan nanozeolit alam pada campuran polipropilene glikol dan toluene diisosianat. Hasil analisis particle size analyzer menunjukkan ukuran partikel nanozeolit Sarulla adalah 95,8 nm. Hasil XRF menunjukkan bahwa komposisi utama nanozeolit Sarulla adalah $\mathrm{SiO}_{2}(80,98 \%)$ dan $\mathrm{Al}_{2} \mathrm{O}_{3}$ (14,21\%), sementara hasil XRD menunjukkan bahwa nanozeolit Sarulla adalah jenis Mordenit. Variasi perbandingan persen berat nanozeolit sebagai bahan pengisi terhadap polipropilene glikol dan toluene diisosianat adalah $(0,5,10,15,20$ dan 25)\%. Hasil spektrum FTIR busa poliuretan dan nanokomposit busa poliuretan menunjukkan gugus fungsi yang hampir sama, hal ini diakibatkan oleh interaksi yang terjadi antara busa poliuretan dan nanozeolit adalah reaksi fisika.

Kata kunci : nanokomposit, busa poliuretan, zeolit alam,dan FTIR

\section{PENDAHULUAN}

$$
\text { Polimer yang dapat }
$$

dimanfaatkan dan dikembangkan sebagai bahan busa adalah poliuretan. Poliuretan selain sebagai bahan busa, saat ini dimanfaatkan sebagai bahan elastomer, perekat dan pelapis.Busa poliuretan diklasifikasikan sebagai busa fleksibel, semi-kaku atau kaku tergantung pada sifat mekanik dan kerapatannya (Cinelli,et al., 2013).

Busa poliuretan umumnya tidak tahan dengan suhu yang tinggi dan akan mengalami degradasi, sehingga diperlukan usaha untuk mengatasi permasalahan itu. Berbagai cara telah dilakukan untuk mengatasi sifat busa poliuretan yang tidak tahan terhadap suhu yang tinggimisalnya memodifikasi busa poliuretan dengan bahan pengisi clay, $\mathrm{CaCO}_{3}$ dan bentonit. Xia Cao, et al., (2004) melaporkan bahwa pengisi bentonit yang ditambahkan pada poliuretan dapat meningkatkan $\quad T g$ (Temperature glass) poliuretan sebesar $6^{\circ} \mathrm{C}$. Disisi lain penelitian nano komposit busapoliuretan telah banyak diteliti oleh beberapa peneliti baik dari sifat termal, morfologi, mekanikdanperedamsuara (sound damping) dengan menggunakan berbagai pengisi diantaran yanano komposit clay dengan poliuretan. Sangram, et al., (2014) melaporkan bahwa pengisi clay mampumem perkecil pori-pori dari poliuretan sehingga meningkatkan sifat termal secara signifikan dengan menggunakan TEM dan juga penelitian ini membuktikan tidak 
adanya reaksi kimia akan tetapi anali saserapan infra merah membuktikan adanya interaksi fisika antara clay dan poliuretan, oleh karena itu peningkataninteraksi fisika pada konsentrasiclay tertentu yang ditambahkan dapat meningkatkan sifat mekanik terutama tensile strength (tegangan dan regangan).

Pada penelitian ini busa poliuretan dimodifikasi dengan penambahan pengisi nanozeolit yang bertujuan agar zeolit terdistribusi merata pada busa poliuretan. Penggunaannan ozeolit sebagai pengisi dalam busapoliuretandi karenakan zeolit merupakan senyawa alumina silikat yang tersusun dari logam-logam seperti logam aluminium, natrium, besi, dan sebagainya tergantung pada jenis zeolitnya(Makadia, 2000; Cho, et al.,2000; Paul, et al., 2000).

Zeolitalam dibeberapa daerah di Indonesia sangatbesar dan berpotensi untuk dikembangkan, zeolit yang sangatmelimpahtersebut, tersebar di berbagaidaerahdi pulauJawa, Sumatera, dan Sulawesi.Salah satusumberzeolitalam yang terdapat di Propinsi Sumatera Utara adalah di daerahSarulla, Kecamatan Pahae, Kabupaten Tapanuli Utara, Propinsi Sumatera Utara. Berdasarkan hasil pemetaan yang dilakukan jumlah cadanganzeolit di daerah Sarulla, KecamatanPahae, Kabupaten Tapanuli Utara berjumlah 3.340.000 ton (Balitbang SU., 2006).

Nanokompositbusapoliuretan dipreparasi dalam konsentrasipersenyang berbeda, dengan harapan diperoleh material nanokompositbusapoliuretan yang memiliki sifat termal yang lebih baik dari material asalnya, disampingitu juga akan dilihat perubahan gugus yang dihasil kandari reaksi antara kedua komponen. Harapan dari penelitianini adalah memberikanmasukanpada industri furnitureaplikasi matras.

\section{TINJAUAN PUSTAKA}

\subsection{Poliuretan}

Poliuretan merupakan bahan polimer yang mempunyai ciri khas gugus fungsi uretan (-NHCOO-) dalam rantai utama polimer.Gugus fungsi uretan dihasilkan dari reaksi antara isosianat dengan senyawa 
yang mengandung gugus hidroksil (Ashida, 2007).

Secara prinsip, poliuretan dapat dibuat dengan cara mereaksikan dua bahan kimia reaktif yaitu poliol dengan diisosianat, dan biasanya ditambahkan sejumlah aditif untuk mengontrol proses reaksi dan memodifikasi produk akhir (Woods, 1990).Secara sederhana, reaksi pembentukan poliuretan dapat dituliskan sebagai berikut:

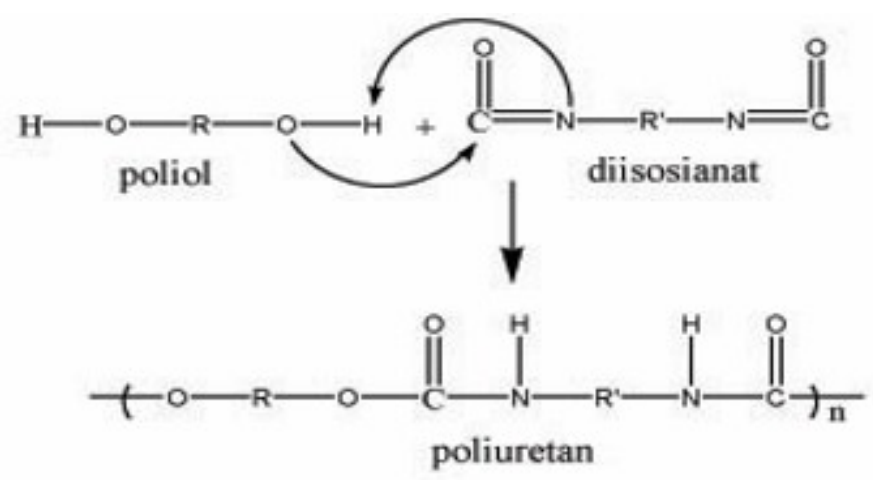

Gambar 1. Reaksi Pembentukan Poliuretan

Jenis isosianat, poliol ataupun pemanjang rantai yang digunakan dalam sintesis poliuretan akan memengaruhi kecepatan reaksi dan sifat dari produk akhir yang dihasilkan. Poliol memberikan fleksibilitas yang tinggi pada struktur poliuretan sehingga poliol disebut sebagai segmen lunak dari poliuretan. Disisi lain, isosianat dan pemanjang rantai memberikan kekakuan atau rigiditas dalam struktur poliuretan sehingga sering disebut sebagai segmen keras.
Poliuretan adalah jenis polimer yang sangat unik dan luas pemakaiannya.Poliuretan ditemukan pada tahun 1937 oleh Prof. Otto Bayer sebagai pembentukserat yang didesain untuk menandingi serat nilon.Tetapi penelitian lebih lanjutmenunjukkan bahwa poliuretan bukan saja bisa digunakan sebagai serat, tapidapat juga digunakan untuk membuat busa (foam)(sekitar 70\%), bahan elastomer(karet/plastik), bahan perekat, dan pelapis (coating) (Goud, et al., 2006). 
Berdasarkan struktur selnya, foam dibedakan menjadi dua, yaitu: sel tertutup (closed cell) dan sel terbuka (opened cell). Foam struktur sel tertutup (closed cell) tidak memiliki jaringan sel yang terhubung.Foam dengan struktur sel tertutup merupakan bahan foam padat/rigid foam (foam kaku seperti pada insulasi kedap suara). Biasanya jenis foamini memiliki kuat tekan yang lebih tinggi karena strukturnya, memiliki stabilitas dimensi yang lebih tinggi, serapan air rendah dan memiliki kekuatan yang lebih tinggi jika dibandingkan foam sel terbuka (opened cell). Foam dengan struktur sel terbuka (opened cell) mengandung pori-pori yang saling terhubung satu sama lainnya untuk membentuk jaringan interkoneksi. Jenis foam ini memiliki kerapatan relatif lebih rendah dan penampilannya seperti spons/flexible foam (foam fleksibel seperti kasur busa, alas kursi dan jok mobil) (Szycher, 2013).

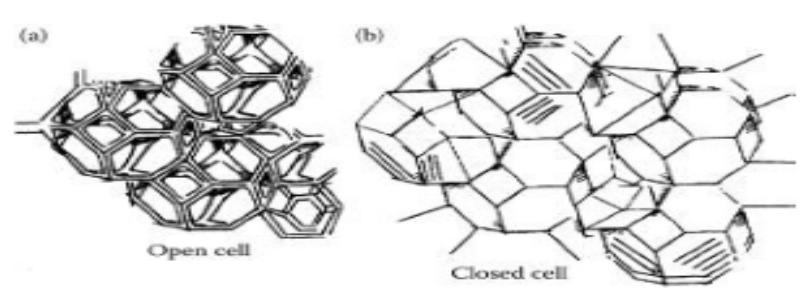

Gambar 2. (a). Foam struktur sel terbuka (open cell) dan (b). Foam struktur sel tertutup (closed cell) (Szycher, 2013)

\subsection{Zeolit Alam}

Zeolit alam terbentuk karena adanya proses kimia dan fisika yang kompleks dari batuan-batuan yang mengalami berbagai macam perubahan di alam. Para ahli geokimia dan mineralogi memperkirakan bahwa zeolit merupakan produk gunung berapi yang membeku menjadi batuan vulkanik, batuan sedimen dan batuan metamorfosa yang selanjutnya mengalami proses pelapukan karena pengaruh panas dan dingin (Lestari, 2010).

\subsection{PembentukanBusa Poliuretan}

Terdapat dua sistem yang dapat digunakan untuk membentuk poliuretan yaitu: sistem one-step 
(one-shot process) dan sistem twostep (prepolymer process). Sistem one-step(one-shot process) umumnya digunakan dalam pembentukan busa poliuretan, sedangkan sistem two-step (prepolymer process) diaplikasikan pada produksi elastomer.

Reaksi-reaksi ini diilustrasikan pada Gambar 3. dan Gambar 4. di bawah ini:

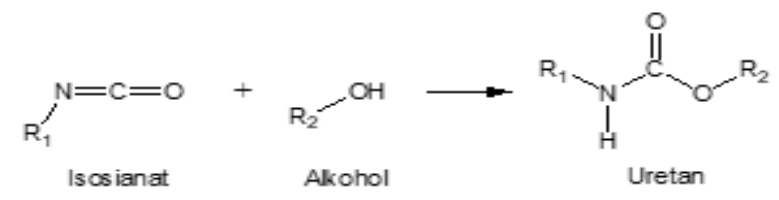

Gambar 3. Reaksi gel (Edward, 1981)

a)<smiles>[R18]N=C=O</smiles>

b)



c)
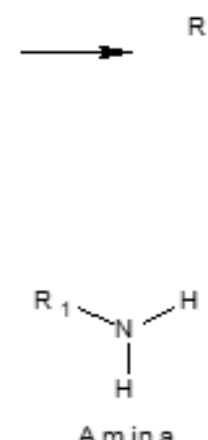<smiles>[R1]N[14CH2][14CH2][14CH2][14CH2][14C](=O)[O-]</smiles><smiles>C1CCC1</smiles><smiles>[R8]N([2H])C(=O)N([R8])[13CH2]</smiles>

Gambar 3. Reaksi pembentukan busa poliuretan a).reaksiblow-tahap awal, b). reaksiblow-tahap dekomposisi), dan c). reaksiblow-pembentukan urea (Edward, 1981).

\subsection{Zeolit}

Mineral zeolit telah dikenal sejak tahun 1756 oleh Cronstedt ketika menemukan Stilbit yang bila dipanaskan seperti batuan mendidih (boiling stone) karena dehidrasi molekul air yang dikandungnya.Pada tahun 1954 zeolit diklasifikasi sebagai golongan mineral tersendiri, yang saat itu dikenal sebagai molecular sieve materials. 
Aktivasi secara kimia dapat juga dilakukan melalui pencucian zeolit dengan larutan $\mathrm{Na}_{2}$ EDTA atau asam-asam anorganik seperti: HF,
$\mathrm{HCl}$ dan $\mathrm{H}_{2} \mathrm{SO}_{4} \quad$ untuk menghilangkan oksida-oksida pengotor yang menutup (Setiadi dan Astri Pertiwi, 2007).
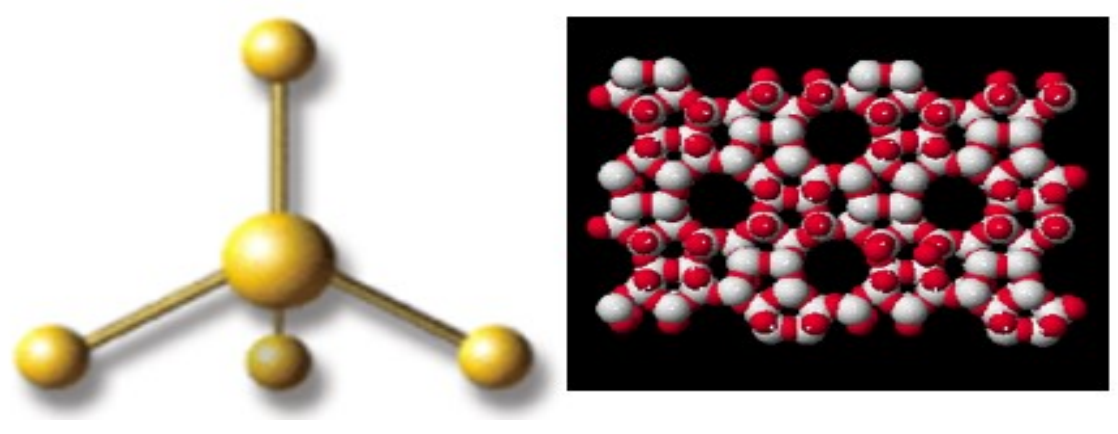

Gambar 4. Kristal zeolit tiga dimensi yang dibangun oleh tetrahedral $\mathrm{AlO}_{4}$ dan $\mathrm{SiO}_{4}$

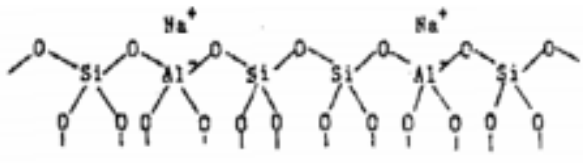

Struktur permukaan zeolit
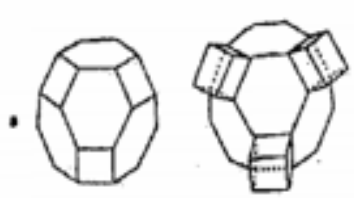

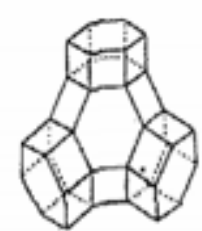

(

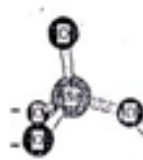<smiles>[Te]=[Te]</smiles>
$-8$

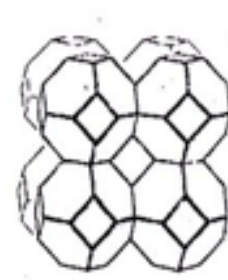

Sndalit

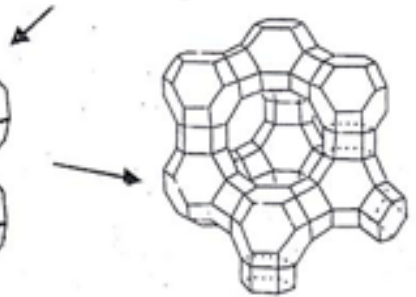

Faujasit

Permukaan kerangka dasar zeolit (sodalit)

Gambar 5. Struktur molekul zeolit

\subsection{Nanoteknologi}

Nanoteknologi adalah ilmu dan rekayasa dalam menciptakan material,struktur fungsional, maupun piranti alam skala nanometer.Material berukurannanometer memiliki sejumlah sifat kimia dan fisika yang lebih unggul dari materialberukuran besar (bulk).Disamping itu material dengan ukuran nanometer memilikisifat yang kayakarena menghasilkan sifat yang tidak dimiliki oleh material ukuranbesar. 
Sejumlah sifat tersebut dapat diubahubah dengan melalui pengontrolan ukuranmaterial,pengaturan

komposisi kimiawi, modifikasi permukaan, dan pengontrolaninteraksi antar partikel (Abdullah, 2009).

$\begin{array}{lll} & \text { Nanoteknologi merupakan } \\ \text { suatu teknologi yang dihasilkan }\end{array}$ daripemanfaatan sifat-sifat molekul atau struktur atom apabila berukuran nanometer. Jadi apabilamolekul atau struktur dapat dibuat dalam ukuran nanometer maka akan dihasilkan sifat-sifatbaru yang luar biasa. Sifatsifat baru inilah yang dimanfaatkan untuk keperluan teknologisehingga teknologi ini disebut nanoteknologi (Abdullah dan Khairurrijal, 2010).

\subsection{Karakterisasi}

Karakterisasi polimer merupakan bagian yang sangat penting dalam suatu industri polimer guna menentukan aplikasi dari polimer. Aplikasi polimer ini ditentukan oleh sifat yang dimiliki oleh bahan polimer tersebut. Dari hasil pembuatan sampel nanozeolit alam, maka dilakukan beberapa karakterisasi meliputi: analisis PSA, XRD, dan SEM. Hasil nanokomposit busa poliuretan dengan bahan pengisi nanozeolit alam maka dilakukananalisis FTIR.

\section{METODE PENELITIAN}

\section{Proses Persiapan dan Pemurnian Zeolit Alam}

Pada tahapan ini,sampel zeolit alam diperoleh dari daerah Sarulla, Kecamatan Pahae, Kabupaten Tapanuli Utara, Propinsi Sumatera Utara.Sampel zeolit alam Sarulla dilakukan peremukan (crushing) dan penggerusan (grinding) hingga berbentuk serbuk halus sehingga lolos pada mata ayakan 200 mesh (74 mikrometer). Kemudian di aktivasi dengan penambahan 300 mllarutan $\mathrm{HCl} 0.05 \mathrm{~N}$, lalu diaduk sampai homogen dengan menggunakan magnetik stirer selama 1 jam pada suhu $70^{\circ} \mathrm{C}$, selanjutnya didiamkan selama 1 malam.Setelah itu disaring dengan menggunakan kertas saring dengan tujuan untuk memisahkan larutan $\mathrm{HCl}$ dengan zeolit alam, kemudian dilakukan pencucian ulang dengan menggunakan air aquades dan kembali memisahkan antara zeolit alam dengan air aquades sampai diperoleh $\mathrm{pH}$ netral. 


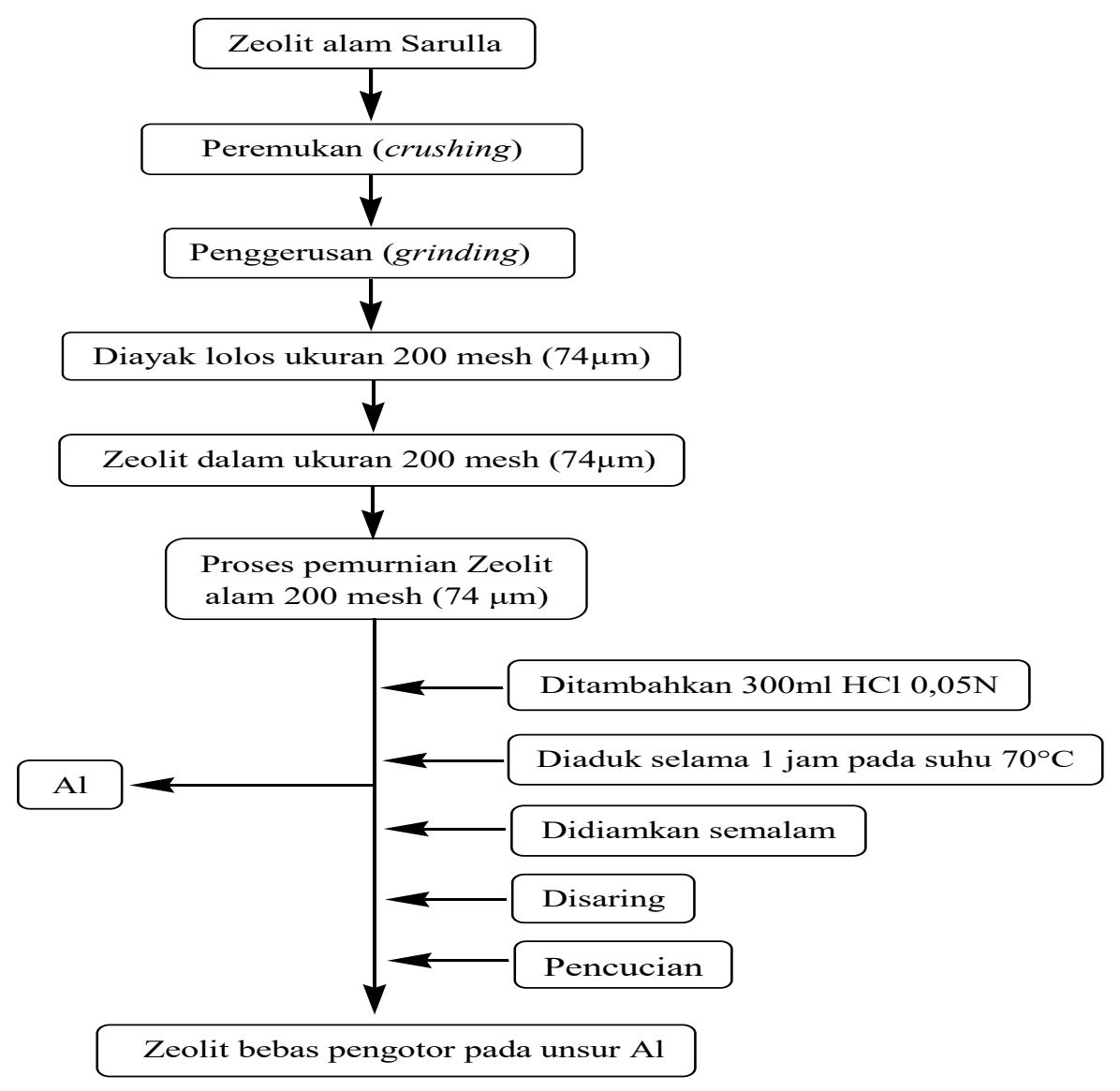

Gambar 6. Diagram alir proses persiapan dan pemurnian zeolit alam

\section{Proses Pembuatan Nanozeolit}




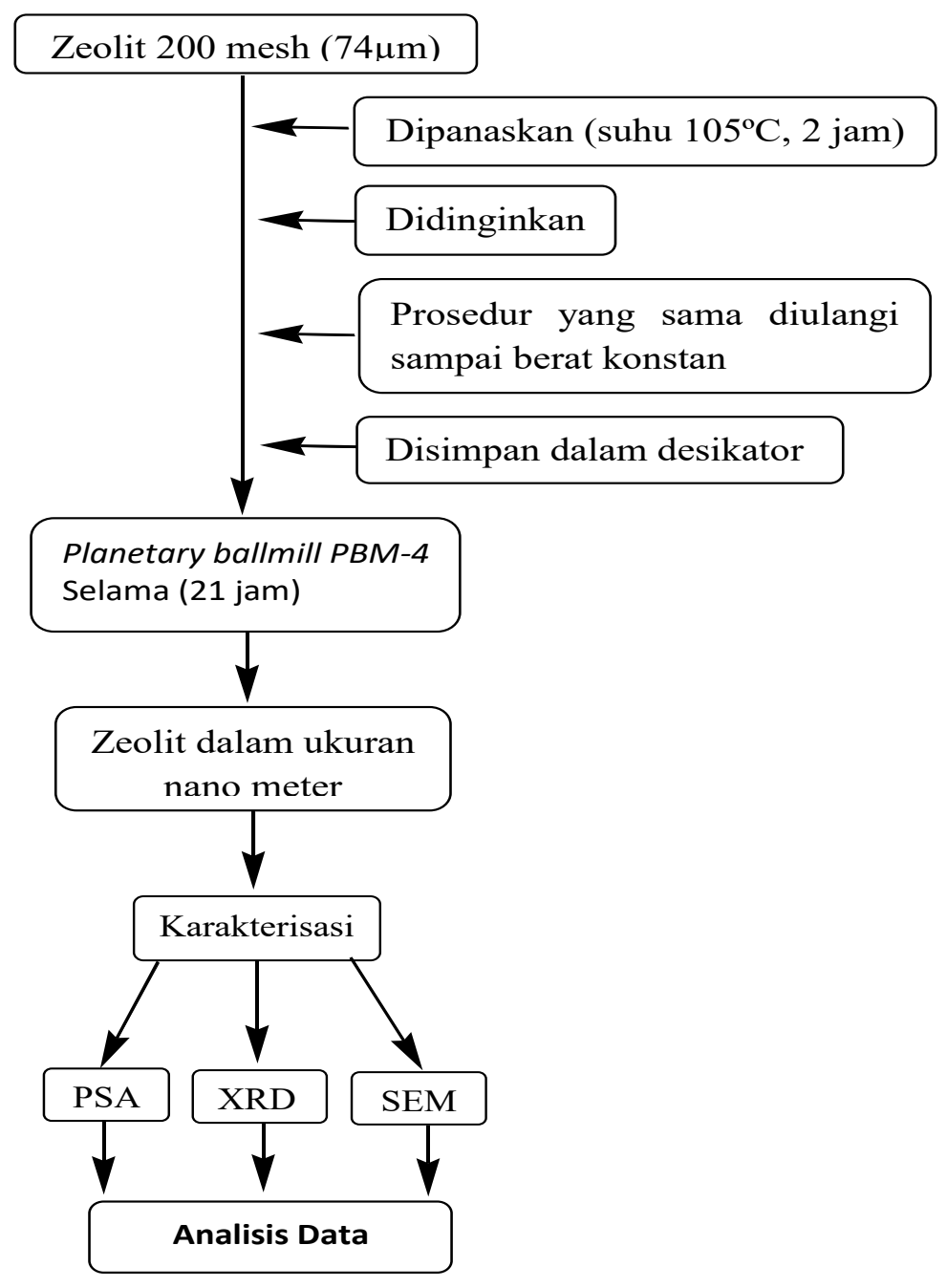

Gambar 7. Diagram Alir Proses Pembuatan Nanozeolit

\section{Proses Pembuatan Nanokomposit Busa Poliuretan}




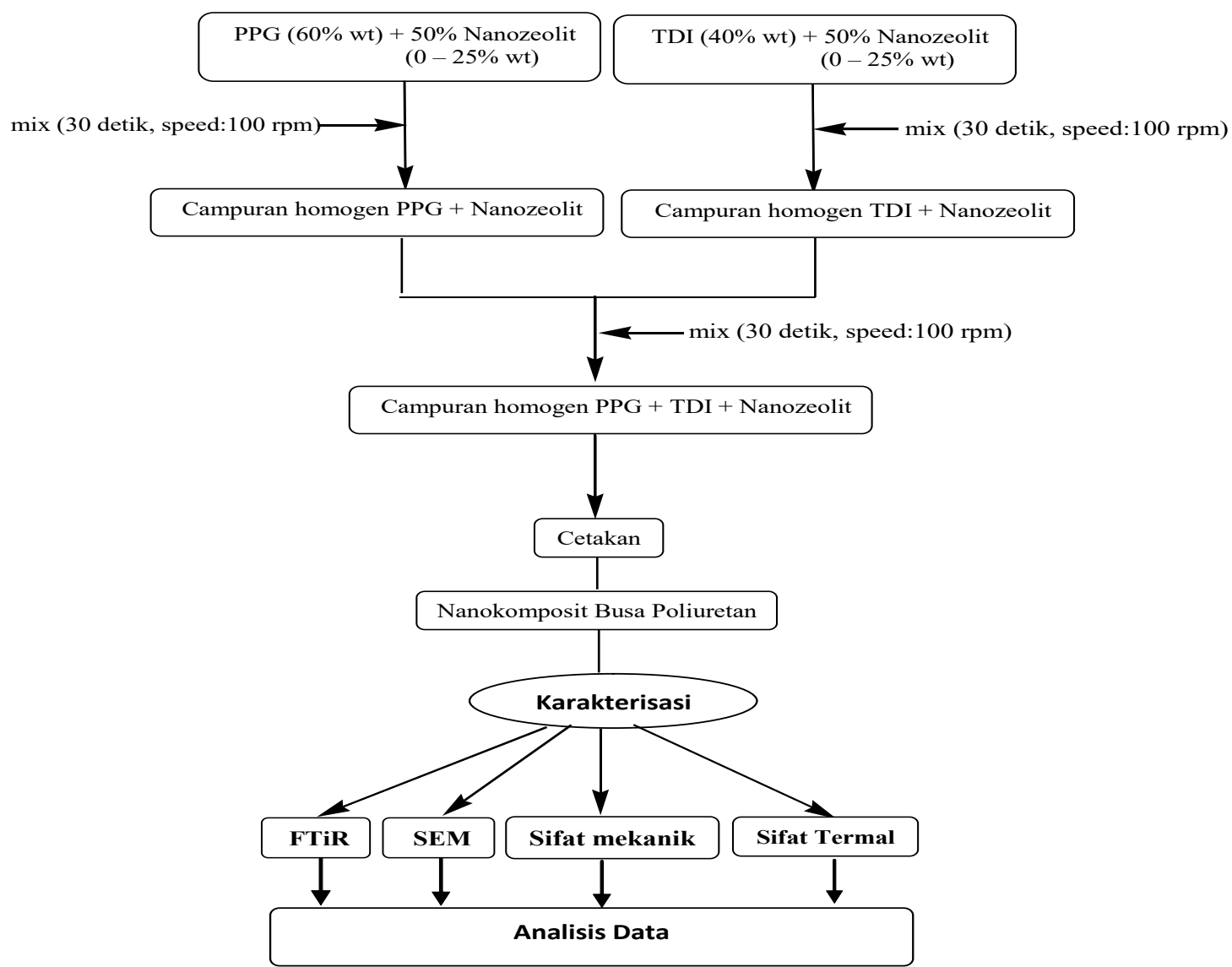

Gambar 8. Diagram Alir Proses Pembuatan Nanokomposit Busa Poliuretan

\section{HASIL DAN PEMBAHASAN}

\subsection{Nanozeolit}

Zeolit alam yang digunakan pada penelitian ini adalah zeolit alam yang diperoleh dari daerah Sarulla, Kecamatan Pahae, Kabupaten Tapanuli Utara, Propinsi Sumatera Utara dengan ciri fisik berwarna putih kecoklat-coklatan. Sebagai salah satu material yang melimpah di alam, zeolit mengandung berbagai material lain seperti air dan pengotor dari senyawa organik.Oleh karena itu, perlu dilakukan preparasi terhadap zeolit alam sebelum diaplikasikan.

Aktivasi zeolit secara kimia dilakukan dengan tujuan untuk membersihkan permukaan pori dan membuang senyawa pengotor. Proses aktivasi zeolit dengan perlakuan asam $\mathrm{HCl}$ menyebabkan zeolit mengalami dealuminasi dan dekationisasi yaitu keluarnya $\mathrm{Al}$ dan 
kation-kation dalam kerangka zeolit permukaan yang bertambah sertaberdampak terhadap diharapkan meningkatkan bertambahnya luas permukaan zeolit kemampuan zeolit dalam proses karena berkurangnya pengotor yang penyerapan.

menutupi pori-pori zeolit. Luas

\subsection{Karakterisasi Nanozeolit}

Zeolit alam sebelum preparasi ini dapat dilihat pada Gambar. di bawah ini.
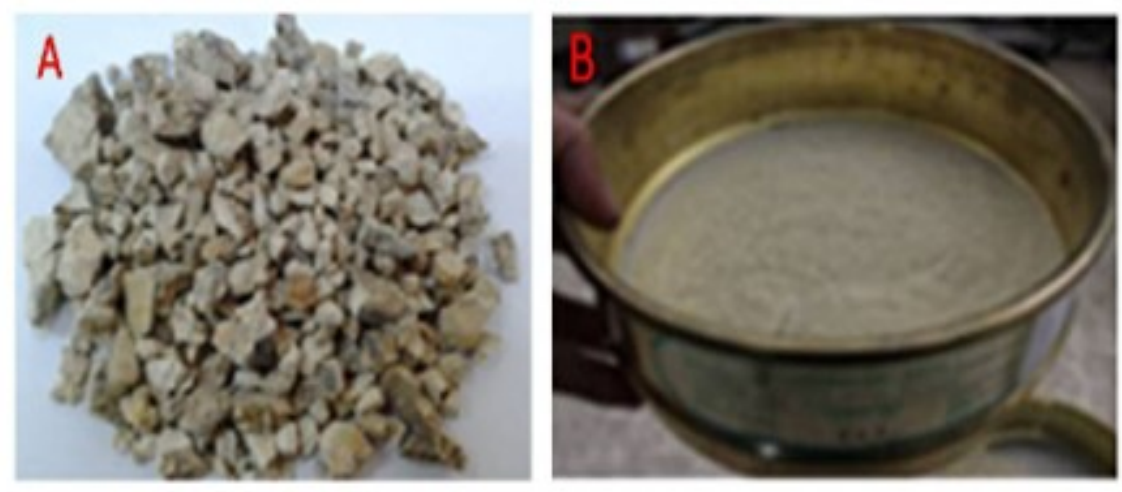

Gambar 9.a). Zeolit Alam dan b). Zeolit ukuran 200 mesh (74 mikrometer)

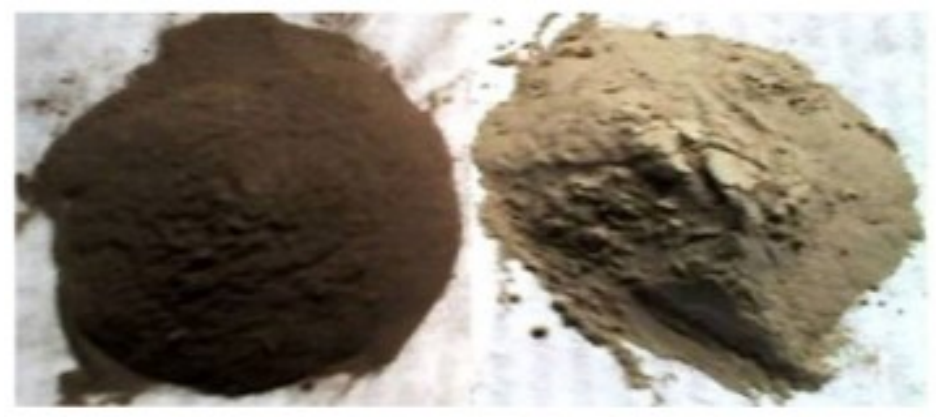

Gambar 10. Nanozeolit alam sebelum (kiri) dan sesudah (kanan) aktivasi

Nanozeolit yang diperoleh dengan ukuran partikel $95,8 \mathrm{~nm}$ atau lebih rendah dari hasil yang diperoleh beberapa peneliti sebelumnya, diharapkan dengan semakin kecil ukuran partikel akan didapatkan luas permukaan yang lebih besar, yang mana dengan luas permukaan yang lebih besar pada zeolit ini akan terjadi penyebaran 
yang lebih baik dalam bahan pengisi dalam ukuran penggunaannya sebagai bahan nanometer akan memberikan hasil pengisi pada busa poliuretan, karena yang lebih baik dibandingkan bila Fatimah dan Wijaya (2006) menggunakan bahan pengisi dalam menyatakan dengan memanfaatkan ukuran mikrometer.

\subsection{Karakterisasi dengan FTIR}

Adapun hasil karakterisasi busa poliuretan dan nanokomposit busa poliuretan ditunjukkan pada Gambar di bawah.

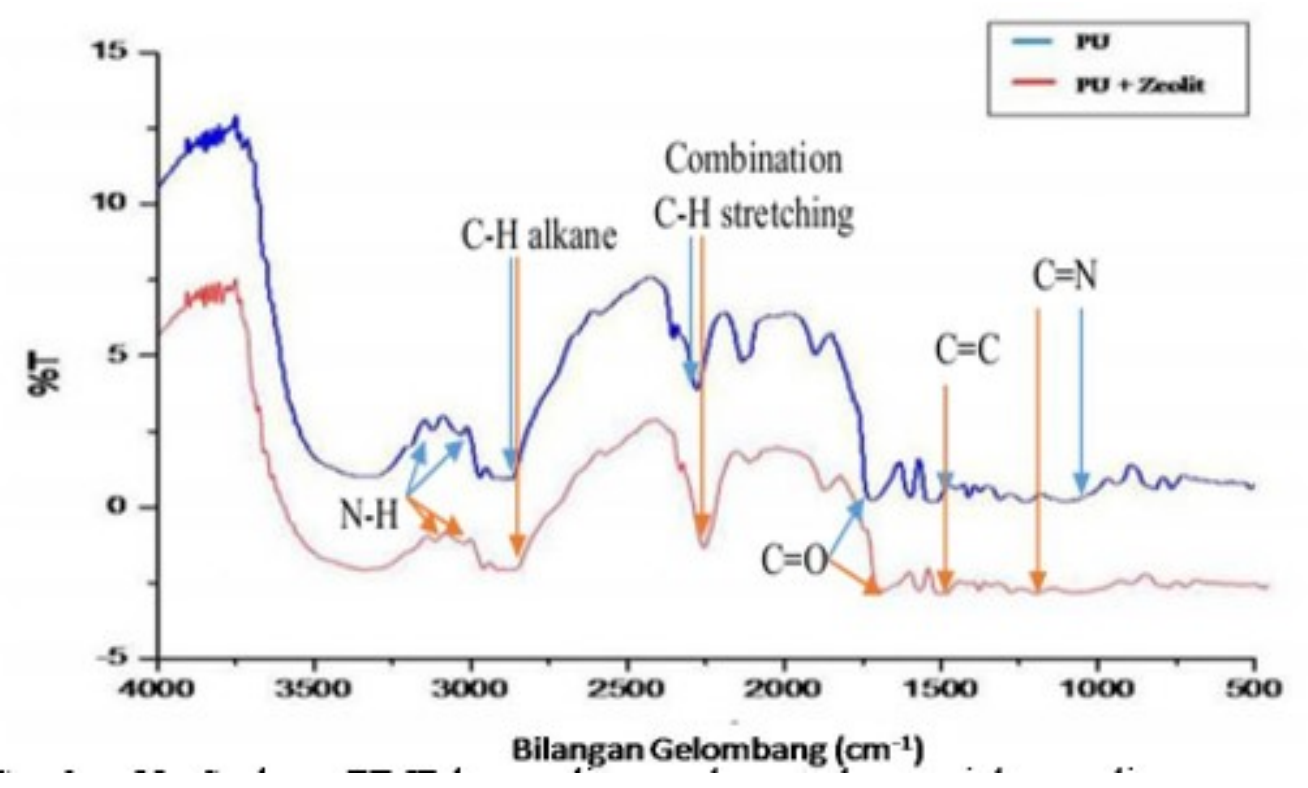

Gambar 11. Spektum FT-IR busa poliuretan dan nanokomposit busa poliuretan

Tabel 1 .Daerah serapan untuk busa poliuretan dengan nanokomposit busa poliuretan

\begin{tabular}{lll}
\hline \multicolumn{1}{c}{ Gugus Fungsi } & \multicolumn{2}{c}{ Bilangan Gelombang $\mathbf{~ c m}^{-1}$} \\
\cline { 2 - 3 } & \multicolumn{1}{c}{ Busa Poliuretan } & Nanokomposit Busa Poliuretan \\
\hline N-H & 3120,82 dan 3352,28 & 3120,82 dan 3344,57 \\
C-H (alkana) & 2927,94 dan 2970,38 & 2924,09 dan 2970,38 \\
C $=$ O & 1724,36 & 1720,50 \\
\hline
\end{tabular}




\begin{tabular}{lll}
\hline $\mathrm{C}=\mathrm{C}(\mathrm{TDI})$ & 1543,05 dan 1597,06 & 1543,05 dan 1600,92 \\
$\mathrm{C}-\mathrm{H}$ (aromatik) & 763,$81 ; 821,68$ dan 941,26 & 763,$81 ; 817,82$ dan 933,55 \\
$\mathrm{C}=\mathrm{N}$ & 1087,$85 ; 1230,58$ dan 1311,59 & 1234,44 dan 1311,59 \\
\hline
\end{tabular}

Hasil karakterisasi dengan serapan $1543,05 \mathrm{~cm}^{-1}$ dan $1597,06 \mathrm{~cm}^{-}$ menggunakan spektrum IR padadaerah serapan hampir sama, yaitu $3120,82 \mathrm{~cm}^{-1}$ dan $3352,28 \mathrm{~cm}^{-1}$ untuk busa poliuretan, $3120,82 \mathrm{~cm}^{-}$ ${ }^{1}$ dan $\quad 3344,57 \mathrm{~cm}^{-1}$ untuk nanokomposit busa 1

poliuretanmerupakan gugus NH.Serapan pada daerah $2927,94 \mathrm{~cm}^{-}$ ${ }^{1}$ dan $2970,38 \mathrm{~cm}^{-1}$ untuk busa poliuretan, $2924,09 \mathrm{~cm}^{-1}$ dan merupakan gugus $\mathrm{C}=\mathrm{C} \quad$ dari TDI.Serapan pada daerah $1087,85 \mathrm{~cm}^{-1} ; \quad 1230,58 \mathrm{~cm}^{-1}$; $1311,59 \mathrm{~cm}^{-1} ; \quad 1234,44 \mathrm{~cm}^{-1}$ dan $1311,59 \mathrm{~cm}^{-1}$ merupakan serapan $2970,38 \mathrm{~cm}^{-1}$ untuk nanokomposit busa poliuretan merupakan gugus $\mathrm{C}$ H (alkana). Serapan pada daerah1724,36 $\mathrm{cm}^{-1}$ dan $1720,5 \mathrm{~cm}^{-}$ ${ }^{1}$ merupakan gugus $\mathrm{C}=\mathrm{O}$ dari gugus $\mathrm{C}=\mathrm{N}$ dari senyawa isosianat.

Permukaan zeolit pada umumnya mengandung gugus hidroksil, T-OH ( $=\mathrm{Si}, \mathrm{Al}$, dan $\mathrm{P})$. Berdasarkan reaktivitas gugus hidroksil, maka diperkirakan dapat terbentuk ikatan hidrogen dengan gugus -N-H yang terdapat pada rantai poliuretan. senyawa amida.Pada daerah
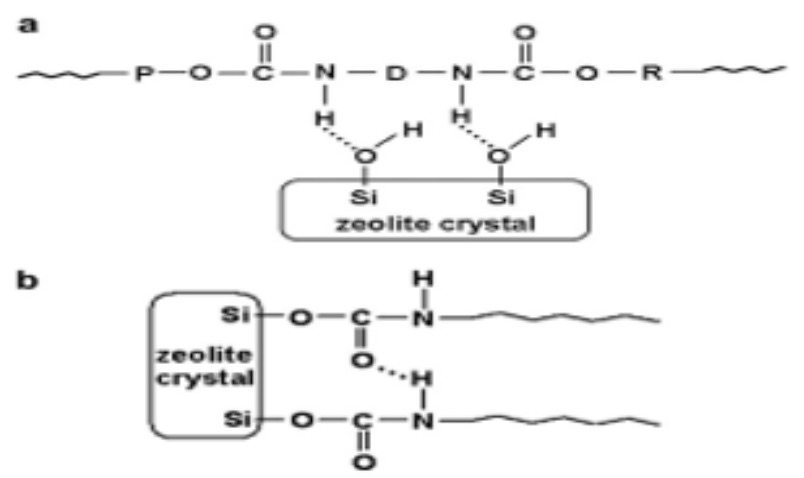

Gambar 12. Kemungkinan a) interaksi fisika, b) interaksi fisika yang terjadi antara zeolit dan poliuretan 
Spektrum FTIR dari

poliuretan pada Gambar (pita biru), menunjukkan bahwa terdapat $\mathrm{N}-\mathrm{H}$ stretching sebagai vibrasi uretan pada $3100-3300 \mathrm{~cm}^{-1}$ dan puncak terpecah menjadi 2 pita, yang disebabkan oleh interaksi intermolekuler yang terjadi dalam uretan, yakni interaksi ikatan hidrogen antara gugus $\mathrm{C}=\mathrm{O}$ dari uretan dengan gugus $\mathrm{N}-\mathrm{H}$ dari molekul uretan lainnya. Sedangkan untuk karakterisasi nanokomposit busa poliuretan dengan menggunakan FTIR dilakukan guna mengetahui perubahan lingkungan kimia yang terjadi antara rantai poliuretan dengan kristal zeolit. Gambar (pita merah dibandingkan dengan pita biru) menunjukkan bahwa

terjadi interaksi fisika, yakni interaksi ikatan hidrogen antara gugus -N-H dari rantai uretan dengan gugus $\mathrm{OH}$ dari zeolit (interaksi ditunjukkan oleh Gambar a). Puncak dengan intensitas rendah pada bilangan gelombang $3220 \mathrm{~cm}^{-1}$ merupakan refleksi dari berlangsungnya interaksi tersebut.Terdapatnya perubahan intensitas dari beberapa puncak sebelum dan sesudah penambahan nanozeolit kemungkinan disebabkan oleh adanya pembentukan crosslinking poliuretan yang disebabkan oleh penambahan nanozeolit sebagai bahan pengisi.

\section{SIMPULAN}

Simpulan yang dapat penulis sajikan dalam tulisan ini adalah bahwa pembuatan nanokomposit busa poliuretan dengan penambahan pengisi nanozeolit alam Sarulla dapat meningkatkan sifat mekanik nanokomposit busa poliuretan. Peningkatan sifat mekanik nanokomposit busa poliuretan diperoleh pada nilai optimum $20 \%$ yaitu hasil spektrum FTIR busa poliuretan dan nanokomposit busa poliuretan menunjukkan gugus fungsi yang hampir sama, hal ini diakibatkan oleh interaksi yang terjadi antara busa poliuretan dan nanozeolit adalah reaksi fisika.

\section{DAFTAR PUSTAKA}

Abdullah, $\quad$ Mikrajuddin. 2009. 
Pengantar Nanosains.

Penerbit ITB. Bandung.

Academie des Science dan Academie des Technologies, 2004.Nanoscience,

Nanotechnologies, $\quad R S T$

No.18.http://www/academies

cience.fr/publications/

rapports/rapportsht/ml/RST1

8htm, diakses tanggal 17

Agustus 2014.

Adebajo MO., Long MA, dan Frost RL., 2004. Spectroscopic and $X R D$ characterization of zeolite catalysts active for the oxidative methylation of benzene with methane. Spectrochim Acta A Mol Biomol Spectrosc. 60(4):791-9.

Aini, Mukharomah Nur dan Lies Indriati. 2007. Proses Pemutihan Zeolit Sebagai Bahan Pengisi Kertas. BS, Vol. 42, No. I, Juni 2007 : 23 -28 .

Akimkhan, MA., 2012, Structural and Ion-Exchange Properties of natural Zeolite, InTech, http://dx.doi.org/10.5772/516 82, diakses tanggal 11Desember 2015.

Anisah, S., Sakti, Y. M., dan Sumarno. 2013. Pengaruh Penggunaan Blowing Agent Methylene Cloride dan Karbondioksida Terhadap Struktur Polyurethane Foam. Jurnal Teknik Pomits. Vol. 1, No. 1; 1-3.
Arryanto, Y., Amini, S., dan Rosyid, M.F., 2007.IPTEK Nano di Indonesia. Terobosan, Peluang, dan Strategi. Edisi 1 , 12-35. Diglossia.Yogyakarta.

BadanPenelitiandanPengembangan Provinsi Sumatera Utara.2006. Kajian Bahan Galian Zeolit Untuk Dimanfaatkan Sebagai Bahan Baku Pupuk. Medan.

Bukit, Nurdin dan Rugaya.2009. Sintesis carbon dari limbah Perkebunan Disertai Analisis Penggunaannya Sebagai Filer Material Kompon Karet dan Breket Arang. Laporan Penelitian Hibah Bersaing DIKTI.

Bukit, Nurdin. 2011. Pengolahan Zeolit Alam Sebagai Bahan Pengisi Nano Komposit Polipropilena dan Karet Alam SIR-20 Dengan Kompatibelizer Anhidrida Maleat-Grafted-

Polipropilena.Disertasi.Univ ersitas SumateraUtara. Medan.

Bussaya Rattanasupa dan Wirunya Keawwattana. 2007.The Development of Rubber Compound based on Natural Rubber (NR) and EthylenePropylene- Diene-Monomer (EPDM) Rubber for Playground Rubber Mat. Kasetsart Journal (Nat. Sci.) $41: 239-247$.

Cinelli, P., Anguillesi, I dan Lazzeri, A., 2013.Green Synthesis of 
Flexible Polyurethane Foams from

Liquefied

Lignin.European Polymer Journal. 49: 1174-1184.

Ciobanu, C.L., Cook, N.J., Pring, A., Damian, G., and Capraru N., 2008.Another look at nagyagite from the type locality, Sacarimb, Romania.Replacement, chemical variation and petrogenetic implications. Mineralogy and Petrology 93, 273-307.

Cowd, M.A., 1991. Kimia Polimer. Terjemahan Harry Firman. ITB. Bandung.

Eddiyanto. 2007.The

Functionalisation

Polymers, Reactive

Processing, Sructure and Performance

Characteristics. Doctor,s Disertasion of Aston University, 10 August 2007.

Graeme J. Millar, Abigail Winnett, Travis Thompson, dan Sara J. Couperthwaite. 2016. Equilibrium studies of ammonium exchange with Australian naturalzeolites. Journal of Water Process Engineering 9 (2016) 47-57.

Gultom Fransiskus, 2015.
Preparation and
Characterization of Polyol
Natural Rubber Latex Based
Polyurethane Foam. Agrium
ISSN 0852-1077 (Print) ISSN
2442-7306 (Online).April
2015 Volume 19 No.2.

Gultom Fransiskus, 2015. Preparation of Sarulla Natural Nanozeolite as a Filler for Polyurethane Foam Polymer. Agrium ISSN 08521077 (Print) ISSN 2442-7306 (Online) Oktober 2015 Volume 19 No.3.

Gultom Fransiskus, Basuki Wirjosentono, Thamrin, Hamonangan Nainggolan, dan Eddiyanto. 2015.Preparation and Characterization from Natural Zeolite Sarulla of North Sumatera Polyurethane Nanocomposite Foams. Chemistry and Materials Research.ISSN 2224- 3224 (Print) ISSN 2225- 0956 (Online).Vol.7 No.10, 2015.

Gultom Fransiskus, Basuki Wirjosentono, Thamrin, Hamonangan Nainggolan, dan Eddiyanto. 2016.Preparation and characterization of North Sumatera natural zeolitepolyurethane

nanocomposite foams for light-weight engineering materials. Procedia Chemistry 19 ( 2016 ) 1007 1013. Available online at www.sciencedirect.com.Scie nceDirect.Elsevier.

Gultom Fransiskus, Basuki Wirjosentono, Thamrin, Hamonangan Nainggolan, dan Eddiyanto. 2016. Preparasi Zeolit Alam Sarulla Kecamatan Pahae Kabupaten TapanuliUtara Propinsi 


$\begin{array}{lrr}\text { Sumatera Utara Sebagai } & \text { Dalam } \\ \text { Bahan Pengisi r Dan } & \text { AplikasiNanokomposit Busa } \\ \text { Poliuretan. Prosiding Seminar } \\ \text { Nasional Kimia dan } \\ \text { Pendidikan Kimia 2016.ISBN } \\ \text { :978-602-432-004-2. }\end{array}$

Gultom Fransiskus, 2019. Pengaruh Penambahan Nanozeolit Alam Dalam Preparasi Nanokomposit Foam Poliuretan Terhadap Sifat Mekanik. JURNAL DARMA AGUNG Volume XXVII, Nomor 3, Desember 2019: 1179-1190.

https://jurnal.darmaagung.ac.i d/index.php/jurnaluda/article/ view/377/351.p-ISSN 08527296 (Print) e-ISSN 26543915(Online).

Szycher, Michael. 2013. Szycher's Handbook Of Polyurethanes Second Edition. CRC.Press. New York.

Thamrin, 2003.Saling Tembus Polimer Antara Karet Alam(Sir - 20) Dan Poliuretan Thermoplastik. Jurnal Sains Kimia (Journal Of Chemical Science). Volume 7, 2003.ISSN : 1410 -5152 . 